\title{
Valsalva and modified Valsalva maneuver
}

\section{Mehmet Ali Kobat', Mehdi Karasu \\ ${ }^{1}$ Cardiology Department, Firat University, Elazig, Turkey ${ }^{2}$ Cardiology Department, Patnos State Hospital, Agri, Turke

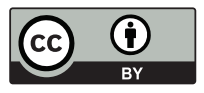 \\ This work is licensed under a Creative Commons Attribution 4.0 International License}

Received: 2020-04-30

Accepted: 2020-05-15

UDC: 616.1

J Clin Med Kaz 2020; 3(57):6-10

Corresponding Author: Mehmet Ali Kobat,

Cardiology Department, Firat University, Elazig, Turkey. Tel.: +905322962880

E-mail: mkobat@firat.edu.tr

\section{Abstract}

Valsalva maneuver is a diagnostic and adjunctive method in non-medical treatment of supraventricular tachycardia, in physical examination, differential diagnosis and imaging-guided evaluation of congenital heart defects and valvular diseases and also to show the presence of autonomic neuropathy caused by diabetes, chronic renal failure, certain cardiomyopathies and neurological disorders. The modified Valsalva maneuver is more effective and less complicated variant of the standard Valsalva maneuver.

Key words: Valsalva, modified Valsalva, cardiovascular reflex

\section{ВАЛЬСАЛЬВА ТӘСІЛІ ЖӘНЕ ВАЛЬСАЛЬВАНЫН ЖАНАРТЫЛҒАН ТӘСІЛІ}

\section{М.А. Кобат ${ }^{1}$, М. Карасу ${ }^{2}$}

'Кардиология кафедрасы, Фират университеті, Элязыг, Түркия

${ }^{2}$ Кардиология бөлімшесі, Патнос мемлекеттік ауруханасы, Агры, Түркия

\section{ТҰЖЫРЫМДАМА}

Вальсальва - бұл қарыншаүстілік тахикардияны медициналық емес емдеудің диагностикалық және көмекші әдісі, фризикалық тексеру, туа біткен жүрек ақаулары мен қақпақшаның ақауларын дифференциалды диагностикалау және визуалды бағалау, сонымен қатар қант диабеті, созылмалы бүйрек жеткіліксіздігі, нақты кардиомиопатия және нейропатия туындаған вегетативті нейропатияның бар-жоғын анықтау үшін. Вальсалваның жаңартылған әдісі - стандартты Вальсальва техникасының тиімділігі көбірек және күрделі емес нұсқасы.

Түйінді сөздер: Вальсальва тәсілі, жаңартылған Вальсальва тәсілі, жүрек-тамыр рефлексі

\section{ПРИЕМ ВАЛЬСАЛЬВЫ И МОДИФИЦИРОВАННЫЙ ПРИЕМ ВАЛЬСАЛЬВЫ}

\section{М.А. Кобат ${ }^{1}$, М. Карасу ${ }^{2}$}

${ }^{1}$ Кафедра кардиологии, Университет Фират, Элязыг, Турция

²Отделение кардиологии,, Государственная больница Патнос, Агры, Турция

\section{PЕЗЮМЕ}

Прием Вальсальвы является диагностическим и вспомогательным методом при немедицинском лечении наджелудочковой тахикардии, при физикальном обследовании, дифференциальной диагностике и визуальной оценке врожденных пороков сердца и клапанных пороков, а также для выявления наличия вегетативной невропатии, вызванной диабетом, хронической почечной недостаточностью, специфической кардиомиопатией и неврологическими расстройствами. Модифицированный прием Вальсальвы это более эффективный и менее сложный вариант стандартного приема Вальсальвы.

Ключевые слова: прием Вальсальвы, модифицированный прием Вальсальвы, сердечно-сосудистый рефлекс

\section{Valsalva maneuver}

The Valsalva maneuver (VM) was first described by Antonio Maria Valsalva [1]. Valsalva maneuver is performed in the form of forced and sudden expiration with the glottis closed (Figure 1). The maneuver should be performed on a specially prepared mercury manometer with an average pressure of 40 $\mathrm{mmHg}$ and end for 10-15 seconds. The expiration should be done abruptly and terminated abruptly [1]. Patients should be allowed to rest in a sitting position for 15 minutes before the test and prevent deep inspiration before expiration. Valsalva maneuver is used for the detection of changes in heart rate and blood pressure values due to autonomic neuropathy, as well as for the diagnosis of heart valve disease, congenital heart disease and evaluation of left ventricular function [2]. Valsalva maneuver is also a treatment method used in the termination of SVT [3].
Figure 1. Valsalva maneuver is performed in the form of forced and sudden expiration with the glottis closed

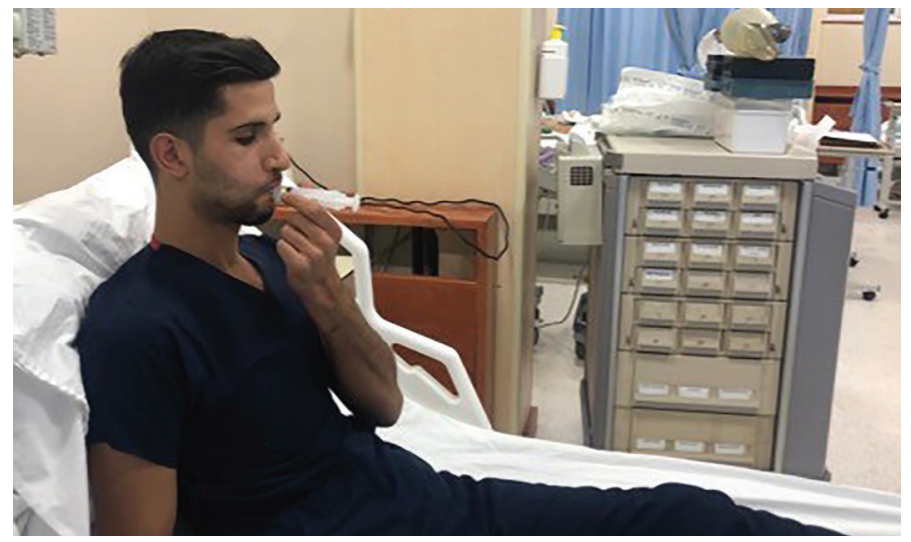

Journal of Clinical Medicine of Kazakhstan: Volume 3, Number 57, Issue 2020 
In the Valsalva maneuver, there are many changes in heart rate and blood pressure through autonomic reflexes [4]. The Valsalva maneuver acts through the baroreceptor reflex network, which is responsible for cardiovascular hemostasis. Baroreceptors (BR) are receptors on the wall of the sinus caroticum and arcus aorta. The excitations from these baroreceptors reach the nervus glossopharyngeus directly through the nervus vagus or via the Hering nerve and from there to the medullary vasomotor center. The response is transmitted to the vascular wall and nodes via the nervus vagus and sympathetic nerves. When BP increases, the number of stimuli transmitted from the BRs to the medullary vasomotor center increases and the vasoconstriction center is inhibited in parallel with this increase while the nervus vagus is stimulated. When blood pressure decreases, the number of stimuli delivered to the medullary vasomotor center decreases and blood pressure increases with peripheral vasoconstriction, while node stimulation increases and heart rate increases [5]. This mechanism through baroreceptors is a response to sudden hemodynamic changes and has no effect on long-term changes.

In the first stage of Valsalva maneuver, intrathoracic pressure increases with forced and sudden expiration and this pressure reflects on the heart and aorta, and blood pressure rises suddenly. As the intrathoracic pressure continues, venous circulation is prevented, and the blood flow to the heart decreases, resulting in the lower left and right heart volumes, cardiac output volume, cardiac output, blood and pulse pressure. Due to the decrease in blood pressure, baroreceptor activity will decrease, and the number of stimuli delivered to the medullary vasomotor center will decrease and as a result, tachycardia will develop. Tachycardia is a reflex response to a drop in blood pressure. Peripheral vascular resistance develops after approximately 7-8 seconds [6]. Intrathoracic pressure returns to normal and venous return increases with sudden termination of expiration. With the termination of VM, intrathoracic pressure decreases and blood pressure rises above baseline values with the effect of ongoing peripheral vasoconstriction as well as increased return. The increase in BP is followed by an increase in BR reflex response within 3-5 seconds, resulting in vagal bradycardia [7]. This bradycardia is followed by peripheral vasodilatation, which leads to normalization of BP. At this stage, stroke volume increases with the return of peripheral blood to the heart (Table 1) $[8,9]$.

Table 1 Cardiovascular changes occurring during Valsalva maneuver

\begin{tabular}{|l|c|c|c|c|}
\hline & stage-1 & stage-2 & stage-3 & stage-4 \\
\hline Intrathoracic pressure & $\Uparrow \Uparrow$ & - & $\Downarrow \Downarrow$ & - \\
\hline Blood pressure & $\Uparrow$ & $\Downarrow \Downarrow$ & $\Downarrow \Uparrow$ & $\Uparrow$ \\
\hline Venous Return & $\Downarrow$ & $\Downarrow \Downarrow$ & - & $\Downarrow$ \\
\hline Heart rate & - & $\Uparrow \Uparrow$ & $\Uparrow$ & $\Downarrow$ \\
\hline $\begin{array}{l}\text { Peripheral Vascular Resis- } \\
\text { tance }\end{array}$ & - & - & & \\
\hline
\end{tabular}

$\Uparrow:$ Increases $\quad \Uparrow \Uparrow$ : Increases significantly :Does not change $\quad \Downarrow$ : Decreases

$\Downarrow \Downarrow$ : Decreases significantly

The response to the Valsalva maneuver varies depending on the posture during the maneuver in healthy individuals. It was observed that the observed tachycardic response was seen more in the sitting position than the forward-curved position. On the other hand, it was observed that the stroke volume decreased more in the standing and sitting position than in the reclining and tilted position. Blood pressure changes are less observed in the supine position. The posture does not affect the final parts of the Valsalva maneuver. It is better to perform the maneuver in a sitting position where the change in parameters is most prominent, except for the treatment purpose [10]. W h i l e gender difference has no effect on Valsalva, different responses are obtained according to ethnic origin [11].

Valsalva maneuver deteriorates with or without heart disease due to sympathetic vasoregulation and desensitization of BR reflex mechanism in older ages. The increase in vagal bradycardia and $\mathrm{BP}$ is uncertain with age, whereas the decrease in $\mathrm{BP}$ becomes more pronounced. In the elderly, VM has no significant meaning as an adjunct diagnostic method [12-14].

Valsalva maneuver is more effective and safer than the carotid massage in the treatment of SVT for the purpose of treatment. When applied for this purpose, it is recommended to use in the supine position where cardiac output and blood pressure change least [15]. Since Valsalva maneuver carries the risk of sudden cardiac arrest, it should not be tried in elderly and patients with coronary heart disease [16]. It has been shown that Valsalva maneuver can be tried in fascicular tachycardia. Valsalva ratio (VR) provides more objective data compared to maneuver in the evaluation of autonomic neuropathy. The ratio of the longest R-R distance to the shortest R-R distance at the time of the test is Valsalva ratio, which is 1.21 or higher in healthy individuals. Decreasing VR below 1.10 is pathological and in particular, helps in the assessment of autonomic neuropathy (ANP) [17].

VR is affected little by the age of the patient [18]. Decreasing of VR to pathological values in DM is an important criterion indicating the presence of diabetic cardiovascular autonomic neuropathy [19]. However, it has been shown that the test is not helpful in the diagnosis of ANP in young and middle age DM patients under the age of 45 with CVS disease [20]. VR decreases to pathological levels in patients with autonomic neuropathy, such as Parkinson disease, multiple sclerosis, and tabes dorsalis [21,22]. VR is abnormal in fatalities, in patients with chronic renal disease undergoing hemodialysis, liver cirrhosis and primary hyperaldosteronism $[23,24]$. Although the presence of parasympathetic denervation in patients with dilated cardiomyopathy due to Chagas disease can be demonstrated by $\mathrm{VM}$ and VR, it has been reported that the test response does not differ in patients without cardiac involvement and in those who develop Chagas myocarditis [25]. Response to VM may be affected by drugs such as alpha- 1 and beta blockers angiotensinconverting enzyme inhibitors, diuretics, certain tranquillizing, and hypopotasemia [26-28]. Myocardial infarction also causes autonomic neuropathy in some patients and disrupts the response to VM. In cases of heart failure and evident left-to-right shunting, there is no response to Valsalva. 
VM may aid in the differential diagnosis of cardiac murmurs. In hypertrophic cardiomyopathy and mitral valve prolapse, the murmur increases in the early stage of VM and decreases at the end of the maneuver, while in aortic stenosis, mitral stenosis, pulmonary stenosis, tricuspid stenosis, aortic insufficiency, mitral insufficiency, tricuspid insufficiency, pulmonary insufficiency and in ventricular septal defect, the murmur severity decreases during VM and increases after VM. Since the venous return returns to the left heart after pulmonary circulation, the murmurs of the right heart appear earlier than the murmurs of the left heart (Table 2).

Table 2 Changes in cardiac murmurs during Valsalva maneuver

\begin{tabular}{|c|c|c|}
\hline Systolic Murmurs & During VM (Stage-2) & VM (Stage-4) \\
\hline Aortic Stenosis & $\Downarrow \Downarrow$ & $\Uparrow \Uparrow$ \\
\hline IHSS & $\Uparrow \Uparrow$ & $\Downarrow \Downarrow$ \\
\hline Pulmonary Stenosis & $\Downarrow$ & $\Uparrow$ \\
\hline Ventricular Septal Defect & $\Downarrow$ & $\Uparrow$ \\
\hline Mitral Failure & $\Downarrow$ & $\Uparrow$ \\
\hline Mitral Valve Prolapse & $\Uparrow$ and early click & Late click \\
\hline \multicolumn{3}{|l|}{ Diastolic Murmurs } \\
\hline Aortic Failure & $\Downarrow$ & $\Uparrow$ \\
\hline Mitral Stenosis & $\Downarrow$ & $\Uparrow$ \\
\hline Pulmonary Insufficiency & $\Downarrow$ & $\Uparrow$ \\
\hline Austin Flint Murmur & $\Downarrow$ & $\Uparrow$ \\
\hline
\end{tabular}

$\Uparrow$ : Increases $\quad \Uparrow \Uparrow$ : Increases significantly $\quad \Downarrow$ : Decreases $\quad \Downarrow \Downarrow$ : Decreases significantly

It should be known that repeated Valsalva maneuver can cause a number of complications including pulmonary embolism [29]. Ocular complications such as large central preretinal and diffuse hemorrhages, vitreous hemorrhage and purtscher retinopathy may occur in addition to small premacular hemorrhages in the eye [30]. The most feared complication is cardiac arrest, which can occur during changes in hemodynamics.

\section{Modified Valsalva}

In the modified Valsalva maneuver, 45 degrees elevation is applied to the patient's feet immediately after the standard Valsalva maneuver is performed (Figure 2). Thus, venous return and vagal stimulation are increased during the relaxation phase. This increases the effectiveness of Valsalva in SVT. In the REVERT study examining the efficacy of the

Figure 1. Modified Valsalva maneuver is performed by applying a 45 degree height to the patient's feet immediately after the standard Valsalva maneuver is performed.

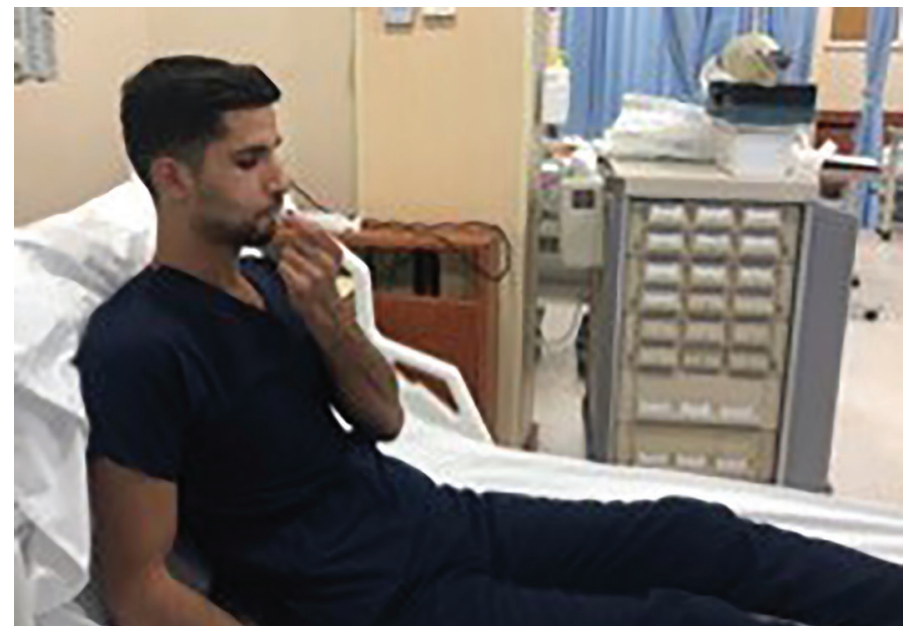

modified Valsalva maneuver, 214 patients underwent Valsalva maneuver and the other 214 patients underwent modified Valsalva maneuver. At the end of 1 minute, termination of SVT was $17 \%(37 / 214)$ in the Valsalva group and $43 \%(93 / 214)$ in the modified Valsalva group. There were no serious side effects in both groups. Side effects (increased heart rate, hypotension, nausea, muscle pain, headache, shortness of breath and cyanosis) were found to be less in the standard Valsalva group (4\% vs $6 \%$ ) [31]. In another single-center randomized controlled trial, modified VM treatment was found to be more effective than

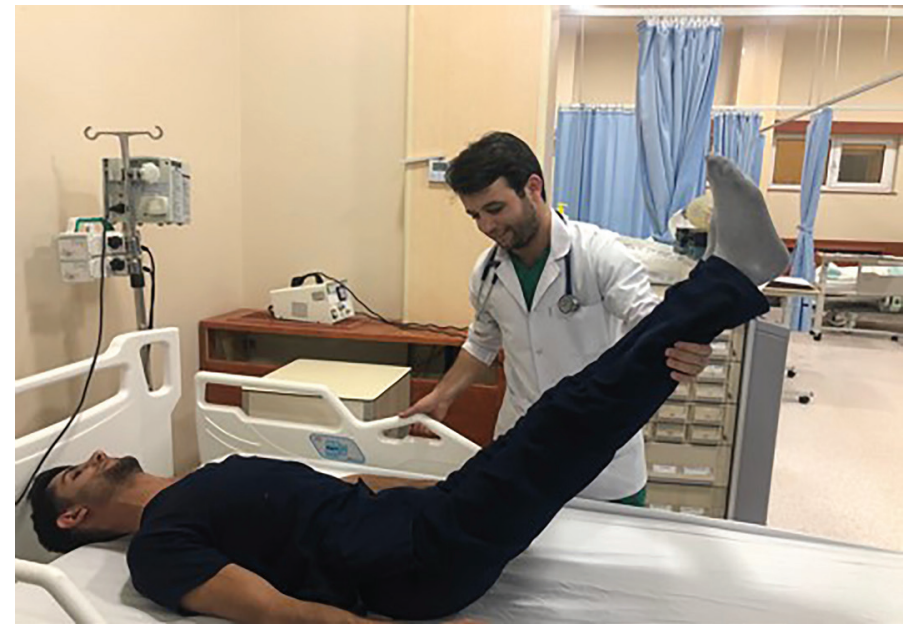

standard VM to terminate SVT [32]. Modified VM treatment reduced the need for anti-arrhythmic drugs and indirectly caused fewer side effects [32]. In a study comparing the impact of maneuvers in the investigation of right-to-left shunt, it was shown that modified Valsalva maneuver revealed shunting much more effectively than standard Valsalva maneuver [33]. In a single-centre randomized controlled trial, the modified Valsalva maneuver was used to treat vasovagal syncope. In this study, tilt table test and vasovagal maneuver were applied to patients due to the formation of vasovagal syncope via baroreceptor reflex 
network. As a result of the study, it was observed that modified Valsalva maneuver increases tolerance to standard maneuver in patients with vasovagal syncope and reduces the risk of syncope formation [34].

\section{Conclusion}

Valsalva and modified Valsalva maneuvers are still essential, despite rapid advances in diagnosis and treatment. Valsalva and modified Valsalva maneuver are of great value, especially in the early treatment of SVT. It is also a good adjunctive diagnostic tool for the assessment of cardiac autonomic neuropathy caused by diabetes and neurological diseases. It provides important clues to the clinician in the evaluation of congenital heart diseases and heart valve diseases in cases where imaging methods are insufficient.

Nevertheless, these maneuvers have little diagnostic value. These maneuvers should not be used in coronary artery disease, decompensated heart failure, hemodynamic disorders and elderly patients. The clinician should be sensitive to patient selection. Modified Valsalva maneuver is preferable to Valsalva maneuver because of its higher efficacy and fewer side effects in the treatment of SVT.

Disclosures: There is no conflict of interest for all authors.

\section{References}

1. Pstras L, Thomaseth K, Waniewski J, Balzani I, Bellavere F. The Valsalva manoeuvre: physiology and clinical examples. Acta Physiol (Oxf). 2016; 217(2):103-19. https://doi.org/10.1111/apha.12639

2. Aparci M, Guney Senol M, Yalcin M, Tansel Kendirli M, Isilak Z. Effective Valsalva maneuvering during TCCD and unrevealed etiology of RLS. Acta Neurol Scand. 2016; 133(4):313-4. https://doi.org/10.1111/ane.12485

3. Smith, G. Management of supraventricular tachycardia using the Valsalva manoeuvre: a historical review and summary of published evidence. Eur J Emerg Med. 2012. 19(6):346-52. https://doi.org/10.1097/MEJ.0b013e32834ec7ad

4. Junqueira LF Jr.Teaching cardiac autonomic function dynamics employing the Valsalva (Valsalva-Weber) maneuver. Adv Physiol Educ. 2008; 32(1):100-6. https://doi.org/10.1152/advan.00057.2007

5. Yang H, Carter JR. Baroreflex sensitivity analysis: spontaneous methodology vs. Valsalva's maneuver. Clin Auton Res. 2013; 23(3):1339. https://doi.org/10.1007/s10286-013-0195-9

6. Davos CH, Davies LC, Piepoli M. The Effect of Baroreceptor Activity on Cardiovascular Regulation. Hellenic J Cardiol. 2002; 43:14555.

7. Yamakawa K, So EL, Rajendran PS, et al. Electrophysiological effects of right and left vagal nerve stimulation on the ventricular myocardium. Am J Physiol Heart Circ Physiol. 2014; 307:H722. https://doi.org/10.1152/ajpheart.00279.2014

8. Yorgancioğlu AC, Tokmakoğlu H. Cardiovascular Function and Physiology. In: Paç M, Akçevin A, Aka SA, Buket S, Sarığlu T editors. Cardiac surgery. 1st ed. MN Medikal and Nobel Ltd Şti. 2014; 21-32.

9. Svacinová J, Moudr J, Honzíková N. Baroreflex sensitivity: diagnostic importance, methods of determination and a model of baroreflex blood-pressure regulation. Cesk Fysiol. 2013; 62(1):10-8.

10. Cameron DA, Kirsh JA: Effect of posture, Valsalva maneuver and respiration on atrial flutter rate: an effect mediated through cardiac volume. J Am Coll Cardiol. 1991; 17:1545. https://doi.org/10.1016/0735-1097(91)90645-P

11. Lu ZY, Metzger BL, Therrien B: Ethnic differences in physiological responses associated with the Valsalva manuever. Res Nurs Health. 1990; 13:9. https://doi.org/10.1002/nur.4770130104

12. Shibasaki K, Ogawa S, Yamada S, Ouchi Y, Akishita M. Role of autonomic nervous activity, as measured by heart rate variability, on the effect of mortality in disabled older adults with low blood pressure in long-term care. Geriatr Gerontol Int. 2018. https://doi. org/10.1111/ggi.13328

13. Strobescu E, Graur M. The cardiovascular reflex tests in autonomic cardiac neuropathy diagnosis. Rev Med Chir Soc Med Nat Iasi. 2002; 106(4):746-52.

14. Hart EC, Charkoudian N. Sympathetic neural regulation of blood pressure: influences of sex and aging. Physiology (Bethesda). 2014; 29(1):8-15. https://doi.org/10.1152/physiol.00031.2013

15. Singer W, OpferGgehrking TL, McPhee BR, Hilz MJ, Low PA. Influence of posture on the Valsalva manoeuvre. Clin Sci (Lond). 2001; 100(4):433-40. https://doi.org/10.1042/cs1000433

16. Walker S, Cutting P. Impact of a modified Valsalva manoeuvre in the termination of paroxysmal supraventricular tachycardia. Emerg Med J. 2010; 27(4):287-91. https://doi.org/10.1136/emj.2009.073866

17. Sukla P, Shrivastava SR, Shrivastava PS, Rao NL. Assessment of the cardiac autonomic neuropathy among the known diabetics and age-matched controls using noninvasive cardiovascular reflex tests in a South-Indian population: A case-control study. Avicenna J Med. 2016; 6(3):81-5. https://doi.org/10.4103/2231-0770.184067

18. Vinik AI, Maser RE, Mitchell BD, Freeman R. Diabetic autonomic neuropathy. Diabetes Care. 2003; 26(5):1553-79. https://doi. org/10.2337/diacare.26.5.1553

19. Matta M, Pavy-Le Traon A, Perez-Lloret S, Laporte C, Berdugo I, Nasr N, Hanaire H, Senard JM. Predictors of Cardiovascular Autonomic Neuropathy Onset and Progression in a Cohort of Type 1 Diabetic Patients. J Diabetes Res. 2018; 2018:5601351. https:// doi.org/10.1155/2018/5601351

20. Vinik AI, Erbas T, Casellini CM. Diabetic cardiac autonomic neuropathy, inflammation and cardiovascular disease. J Diabetes Investig. 2013; 4(1):4-18. https://doi.org/10.1111/jdi.12042

21. Jain S, Goldstein DS. Cardiovascular dysautonomia in Parkinson disease: from pathophysiology to pathogenesis. Neurobiol Dis. 2012; 46(3):572-80. https://doi.org/10.1016/j.nbd.2011.10.025

22. Shirbani F, Barin E, Lee YC, Ng K, Parratt JDE, Butlin M, Avolio AP. Characterisation of cardiac autonomic function in multiple sclerosis based on spontaneous changes of heart rate and blood pressure. Mult Scler Relat Disord. 2018;22:120-127. https://doi org/10.1016/j.msard.2018.03.018 
23. Heart rate response to blood pressure variations: sympathetic activation versus baroreflex response in patients with end-stage renal disease. PLoS One. 2013; 8(10):e78338. https://doi.org/10.1371/journal.pone.0078338

24. Adams SC, Schondorf R, Benoit J, Kilgour RD. Impact of cancer and chemotherapy on autonomic nervous system function and cardiovascular reactivity in young adults with cancer: a case-controlled feasibility study. BMC Cancer. 2015;15:414. https://oi. org/10.1186/s12885-015-1418-3

25. Vasconcelos DF, Junqueira LF. Cardiac autonomic and ventricular mechanical functions in asymptomatic chronic chagasic cardiomyopathy. Jr.Arq Bras Cardiol. 2012; 98(2):111-9. https://doi.org/10.1590/S0066-782X2012005000002

26. Grimm RH Jr, Flack JM. Alpha 1 adrenoreceptor antagonists. J Clin Hypertens (Greenwich). 2011; 13(9):654-7. https://doi.org/10.1111/ j.1751-7176.2011.00510.x

27. Head GA, Saigusa T, Mayorov DN.Braz. Angiotensin and baroreflex control of the circulation. J Med Biol Res. 2002; 35(9):1047-59. https://doi.org/10.1590/S0100-879X2002000900005

28. Sokolow M, Mcllroy MB, Cheitlin MD. Clinical Cardiology, Lebanon, Appleton and Lange. 1990; 624

29. Cheng TO.The proper conduct of Valsalva maneuver in the detection of patent foramen ovale. J Am Coll Cardiol. 2005; 45(7):1145-6. https://doi.org/10.1016/j.jacc.2004.12.054

30. Guigon-Souquet B, Salaun N, Macarez R, Bazin S, De La Marnierre E, Mazdou M. Subhyaloid hemorrhage following a Valsalva maneuver. J Fr Ophtalmol. 2004; 27(10):1159-62. https://doi.org/10.1016/S0181-5512(04)96288-2

31. Appelboam A, Reuben A, Mann C, Gagg J, Ewings P. Postural modification to the standard Valsalva manoeuvre for emergency treatment of supraventricular tachycardias (REVERT): a randomised controlled trial. Lancet. 2015. https://doi.org/10.1016/S01406736(15)61485-4

32. Çorbacıŏglu ŞK, Akıncı E, Çevik Y, Aytar H, Öncül MV, Akkan S, Uzunosmanoğlu H. Comparing the success rates of standard and modifiedValsalva maneuvers to terminate PSVT: A randomized controlled trial. Am J Emerg Med. 2017; 35(11):1662-1665. https:// doi.org/10.1016/j.ajem.2017.05.034

33. Guo YZ, Gao YS, Guo ZN, Niu PP, Yang Y, Xing YQ. Comparison of Different Methods of Valsalva Maneuver for Right-to-left Shunt Detection by Contrast-Enhanced Transcranial Doppler. Ultrasound Med Biol. 2016; 42(5):1124-9. https://doi.org/10.1016/j. ultrasmedbio.2015.12.020

34. He L, Wang L, Li L, Liu X, Yu Y, Zeng X, Li H, Gu Y. A single-center randomized controlled trial observing the safety and efficacy of modified step-up graded Valsalva manoeuver in patients with vasovagal syncope. PLoS One. 2018;13(1):e0191880. https://doi. org/10.1371/journal.pone.0191880

How to cite this article: Valsalva and modified Valsalva maneuver. Mehmet Ali Kobat, Mehdi Karasu. J Clin Med Kaz. 2020; 3(57):6-10 